\title{
Factors Influencing Consumer Buying Behavior \& Awareness towards Organic Food: A Study of Chandigarh \& Panchkula Consumers
}

\author{
Dr. Geetika Sharma ${ }^{1}$, Dr. Rakhee Dewan ${ }^{2}$, Santosh Bali ${ }^{3}$ \\ ${ }^{1}$ SUS College of Engineering \& Technology, College of Management, Mohali, Punjab, India \\ ${ }^{2}$ SUS College of Engineering \& Technology, College of Management, Mohali, Punjab, India \\ ${ }^{3} \mathrm{PhD}$ Research Scholar, Punjab Technical University, Kapurthala, Punjab, India
}

\begin{abstract}
In today's society organic foods are becoming more important, as people have become more and more health conscious. Consumers are aware that what they put into their bodies. Knowing from where our food comes from is the first step to becoming more healthy individuals. Organic foods are grown, processed \& packaged without using artificial fertilizers and without harmful chemical sprays. They are accepted due to their several perceived benefit over the conventional food. The main principle of organic farming is not the most intensive use of resources, but rather their protection and environment-friendly use which lead to sustainability. This study titled "Factors Influencing Consumer Buying Behavior \& Awareness towards Organic Food: A study of Chandigarh \& Panchkula Consumers" will try to focus and to determine the Awareness of Organic Food Products \& to study the purchase behavior, preference \& factors affecting towards organic food of the selected location. This study was based on primary survey of 100 respondents living in the Chandigarh \& Panchkula. Customers were approached randomly using a structured questionnaire. The questionnaire was designed to record the responses on food safety concerns, frequency of buying behavior, from where they buy the products, awareness, attitude, factors effecting buying behavior, price effect on purchasing, behaviors towards organic food and effectiveness of sources for organic information. This study will help to create awareness amongst consumers about organic food by the organic companies.
\end{abstract}

Keywords: Consumer Awareness, Preferences, Organic Food, Organic, Awareness

\section{Introduction}

Organic food market has been rapidly increasing in India. The most important factor on increased production \& consumption of organic products is the change in consumer preferences. Consumers are turning to organic foods because of fears for food safety. Consumers are willing to pay 5-7 \% premium on organic food due to the safety reasons.

According to USDA National Organic Standards Board (NOSB) "Organic agriculture is an ecological production management system that promotes and enhances biodiversity, biological cycles and soil biological activity. It is based on minimal use of off-farm inputs and on management practices that restore, maintain and enhance ecological harmony".

"Organic" refers to food grown without synthetic pesticides, insecticides, herbicides, fungicides, hormones, fertilizers or other synthetic or toxic substances. No artificial flavors or colors are used in production of organic food.

\section{Benefits of Eating Organic Food}

Today consumers choose to buy or eat organic products, they should be able to have confidence that organic food is more nutritious than ordinary produce and it may help to lengthen people's lives and prevent disease. Organic products meet stringent standards. The tastes of Organic food are great. It also reduces health risks. It also built healthy soil $\&$ utilizes the water recourses. It also works in harmony with nature and does innovative research. The production process helps to keep rural community healthy. According to the study of European Union "organic vegetables \& fruits having antioxidants quality and also help to reduce cancer and heart disease risk". Organic food also help to improve resistant system, better sleeping habits. It is also less likely to be overweight than eating conventional food. Organic foods are also tastier and pure than conventional food. Without use of synthetics such as chemical fertilizers and pesticides, organic food is also helpful in saving the environment and also does the animals welfare. This is also produces less waste.

In conventional food production, more use of chemical, fertilizers and pesticides are the reason of the long term damage to the land $\&$ make the land less fertile, which is less in organic food production.

\section{Status of Organic Farming in India}

The total land is under organic farming with 44926 numbers of certified organic farms. This is for about $0.3 \%$ of total agricultural land. Indian organic farming industry is estimated at US\$ 78 million and is almost entirely export oriented. As per the studies there are two types of organic food - certified \& uncertified. Certified products have its production process guaranteed by a certified agency. The product packaging must have the quality assurance. The cost of certification is very high which keep the small farmers out of business. There are few agencies in India which conduct check and issue certificates for Organic food like IMO Control, FKAL international. The OCA has organized a series of National Campaigns to safeguard organic standards 


\section{International Journal of Science and Research (IJSR) \\ ISSN (Online): 2319-7064}

Index Copernicus Value (2013): 6.14 | Impact Factor (2014): 5.611

Food. Food labeled "USDA organic" is the gold standard for health and sustainability. In traditional India, the technique of farming was totally organic. In that time the fertilizers and pesticide were only obtained from plants and animal products. Organic farming was the backbone of the Indian economy. Study shows the diverse interest and belief which motivate their organic food purchasing behavior.

\section{Review of Literature}

Puri and Sangera (1989) conducted a survey to know the consumption pattern of processed products in Chandigarh. Jam was found to be most popular irrespective of income. Orange squash consumption was maximum in high and middle-income families. Pineapple juice consumption increased with a rise in the income.

Sabeson (1992) stated in his study that the major criteria on which the consumers choose a brand of fruits and vegetable is price high quality and taste of the product.

Fagerli and Wandel, 1999 identified that women have higher consciousness and managing the change towards healthier diets to the family because she plays an important role in shaping a family diet.

Gil et al, 2000 suggested that if the price gap of organic and conventional food reduced it defiantly increase the consumption of organic food. The higher price of organic food is the obstruction for consumers in purchasing organic food.

Brown et al. (2000) Authors suggested that food preferences are often of a 'fast food' type and accordingly the food habits of many young consumers may increase the consumption of poorly nutritionally balanced meals. While young consumers were aware of healthy eating, their food preference behavior did not always appear to reflect such knowledge, particularly within the school and social environments. Author reported that the need for effective nutritional education for young consumers has become increasingly clear, given their general food habits and behavior, particularly during teenage years and analyzed that the dealings between young consumers' food preferences and their nutritional awareness behavior, within three environments (home, school and social)

Soil Association, 2000 investigated that women are more committed to good food. Women want to provide natural food and ready to pay premium for environmental good.

Fillion and Arazi, 2002 described consumer felt that organic orange juice is better in taste than conventional orange juice.

Bordeleau et al, 2002 proves that health factor is the most significant factor for choosing organic food. It also develops environmental and animal welfare. Some consumers recognized the difference in food quality and change the preferences towards organic food. Consumers also found the safety and nutrients quality in organic food compared to other.
Baker et al, 2002, Organic food is one of the elements that contribute to sustainable consumption by changing consumption behavior of customer and traditional production system. Organic food is generally pesticide free. Environmental contaminants however are likely to be found in food of both productions. Organic food contains only one third of pesticides that conventional food does.

Sanjuan et al, 2003 According to the study consumer of organic food willing to pay the similar price to those existing at present. The price of organic food is needed to be adjust in Spain.

According to Lockie et al, 2004 the consumers who like to have natural foods are always demand for organic food and engage in green consumption practice.

Lockie et al 2004 Age and income are important factors to motivate the purchasing willingness of organic food.

New York University professor Marion Nestle, recommended that "If you can afford them, buy them," $\mathbf{R}$ Olivas and R Bernabeu (2012) concluded that the organic food consumption can considered the effect of an interaction between eating a healthy diet, respect for the environment and the individual's sociability. He also shows the difference between men \& women consumer's attitudes toward organic food consumption in Spain.

Tomsik \& Kutnohorska, 2013 Find that the organic food market consumer actually shows different attitudes, belief and behaviors in relation to health care. Most of the consumers perceive their health as an important part of their life and they regard organic food as rather healthier than the conventional food.

\section{Objective of Study}

- To study the awareness of organic food products among Chandigarh \& Panchkula Consumers.

- To study the purchase behavior, preference \& factors affecting to purchasing of organic food.

\section{Methodology}

This study was based on primary survey of 100 respondents living in the Chandigarh \& Panchkula. Customers were approached randomly using a structured questionnaire. The questionnaire was designed to record the responses on food safety concerns, Frequency of buying behavior, from where they buy the products, awareness, attitude, factors effecting buying behavior, price effect on purchasing, behaviors towards organic food and effectiveness of sources for organic information. The socio- demographic profiles of the respondents were also recorded on the parameters such as gender, age, education level, occupation, household income and marital status. Simple data analysis techniques were adopted to analyze the data. 


\section{International Journal of Science and Research (IJSR) \\ ISSN (Online): 2319-7064}

Index Copernicus Value (2013): 6.14 $\mid$ Impact Factor (2014): 5.611

Table 1: Statements on which data has been collected

\begin{tabular}{|c|c|c|}
\hline Sno & Statement & \\
\hline 1 & Organic food is healthier than conventional food. & Q 1 \\
\hline 2 & Organic food is good in taste. & Q 2 \\
\hline 3 & Organic food does not contain any preservative. & Q 3 \\
\hline 4 & Organic food is better in quality than conventional \\
food. & Q_4 \\
\hline 5 & Organic food is more Hygienic. & Q_5 \\
\hline 6 & Fruits and vegetables are the healthiest organic food. & Q 6 \\
\hline 7 & $\begin{array}{c}\text { Organic food is less consumed and brought because of } \\
\text { lesser availability in the market. }\end{array}$ & Q_7 \\
\hline 8 & $\begin{array}{c}\text { Organic food is less consumed and brought because of } \\
\text { lack of awareness. }\end{array}$ & Q_8 \\
\hline 9 & $\begin{array}{c}\text { I would rather buy organic food products even though } \\
\text { it is expensive. }\end{array}$ & Q_9 \\
\hline 10 & I prefer to purchase from supermarket/mall. & Q 10 \\
\hline 11 & I prefer to purchase from local market. & Q 11 \\
\hline 12 & I prefer to purchase organic food once a week. & Q 12 \\
\hline 13 & I prefer to buy organic food every fortnight. & Q 13 \\
\hline 14 & I Prefer to purchase organic food monthly & Q 14 \\
\hline 15 & I Prefer to purchase organic food every two months. & Q 15 \\
\hline 16 & $\begin{array}{c}\text { Organic food is comparatively expensive than } \\
\text { conventional food. }\end{array}$ & Q_16 \\
\hline 17 & Organic food does not offer too much variety. & Q 17 \\
\hline 18 & $\begin{array}{c}\text { Organic food is available in good packaging to attract } \\
\text { customers. }\end{array}$ & Q_18 \\
\hline 19 & $\begin{array}{c}\text { The buying of organic food is rationally proportional to } \\
\text { monthly income. }\end{array}$ & Q_19 \\
\hline 20 & $\begin{array}{c}\text { Buying and consuming organic food has become status } \\
\text { syme rich. }\end{array}$ \\
\hline
\end{tabular}

Table 2: Demographic Profile of Respondents

\begin{tabular}{|c|c|c|c|}
\hline \multicolumn{4}{|c|}{ Demographic profile of Respondents } \\
\hline \multirow[t]{5}{*}{1} & Age & No. of Respondents & $\%$ of Respondents \\
\hline & $18-25$ & 46 & $46 \%$ \\
\hline & $25-35$ & 32 & $32 \%$ \\
\hline & above 35 & 22 & $22 \%$ \\
\hline & Total & 100 & \\
\hline \multirow[t]{4}{*}{2} & Gender & No. of Respondents & $\%$ of Respondents \\
\hline & Male & 48 & $48 \%$ \\
\hline & Female & 52 & $52 \%$ \\
\hline & Total & 100 & \\
\hline \multirow[t]{6}{*}{3} & Education & No. of Respondents & $\%$ of Respondents \\
\hline & High school & 5 & $5 \%$ \\
\hline & Under graduate & 35 & $35 \%$ \\
\hline & Graduate & 28 & $28 \%$ \\
\hline & Above graduate & 32 & $32 \%$ \\
\hline & Total & 100 & \\
\hline \multirow[t]{7}{*}{4} & Monthly Income & No. of Respondents & $\%$ of Respondents \\
\hline & $<15000$ & 14 & $14 \%$ \\
\hline & 15000 to $<30000$ & 34 & $34 \%$ \\
\hline & 31000 to $<45000$ & 12 & $12 \%$ \\
\hline & $>45000$ & 8 & $8 \%$ \\
\hline & dependent & 32 & $32 \%$ \\
\hline & Total & 100 & \\
\hline \multirow[t]{4}{*}{5} & Marital Status & No. of Respondents & $\%$ of Respondents \\
\hline & Single & 52 & $52 \%$ \\
\hline & Married & 48 & $48 \%$ \\
\hline & Total & 100 & \\
\hline \multirow[t]{5}{*}{6} & Job Field & No. of Respondents & $\%$ of Respondents \\
\hline & Corporate & 10 & $10 \%$ \\
\hline & Professional & 56 & $56 \%$ \\
\hline & Students & 34 & $34 \%$ \\
\hline & Total & 100 & \\
\hline
\end{tabular}

Results:

Table 3: Organic Food is healthier than Conventional Food

\begin{tabular}{|c|c|c|c|c|c|}
\hline \multicolumn{2}{|c|}{} & Frequency & Percent & $\begin{array}{c}\text { Valid } \\
\text { Percent }\end{array}$ & $\begin{array}{c}\text { Cumulative } \\
\text { Percent }\end{array}$ \\
\hline \multirow{4}{*}{ Valid } & $\begin{array}{c}\text { Strongly } \\
\text { Agree }\end{array}$ & 46 & 46.0 & 46.0 & 46.0 \\
\cline { 2 - 6 } & Agree & 42 & 42.0 & 42.0 & 88.0 \\
\cline { 2 - 6 } & Neutral & 10 & 10.0 & 10.0 & 98.0 \\
\cline { 2 - 6 } & Disagree & 2 & 2.0 & 2.0 & 100.0 \\
\cline { 2 - 6 } & Total & 100 & 100.0 & 100.0 & \\
\hline
\end{tabular}

\section{Interpretation of the Results}

As we can see in the above table that the majority of respondents around $88 \%$ are agree or strongly agree that organic food is healthier than the conventional food and only $2 \%$ of consumers are disagree from the statement. However $10 \%$ of the respondents are neutral in this respect. It shows that the awareness about beneficial aspects of organic food in the consumers is very high.

Table 4: Organic Food is good in Taste

\begin{tabular}{|l|l|l|l|l|l|}
\hline \multicolumn{2}{|c|}{} & $\begin{array}{l}\text { Freque } \\
\text { ncy }\end{array}$ & $\begin{array}{l}\text { Perce } \\
\text { nt }\end{array}$ & $\begin{array}{l}\text { Valid } \\
\text { Percent }\end{array}$ & $\begin{array}{l}\text { Cumulativ } \\
\text { e Percent }\end{array}$ \\
\hline \multirow{7}{*}{ Valid } & $\begin{array}{l}\text { Strongly } \\
\text { Agree }\end{array}$ & 16 & 16.0 & 16.0 & 16.0 \\
\cline { 2 - 6 } & Agree & 40 & 40.0 & 40.0 & 56.0 \\
\cline { 2 - 6 } & Neutral & 38 & 38.0 & 38.0 & 94.0 \\
\cline { 2 - 6 } & Disagree & 4 & 4.0 & 4.0 & 98.0 \\
\cline { 2 - 6 } & $\begin{array}{l}\text { Strongly } \\
\text { Disagree }\end{array}$ & 2 & 2.0 & 2.0 & 100.0 \\
\cline { 2 - 6 } & Total & 100 & 100.0 & 100.0 & \\
\hline
\end{tabular}

Interpretation of the results: According to the results $56 \%$ of the respondents are agree that the organic food is tastier than conventional food. They believe that organic food contains more nutrients. It helps to fight cancer, stroke and heart problems. However 38\% respondents are neutral about the taste of organic \& conventional food. Minority people were disagreeing that organic food is good in taste than conventional food.

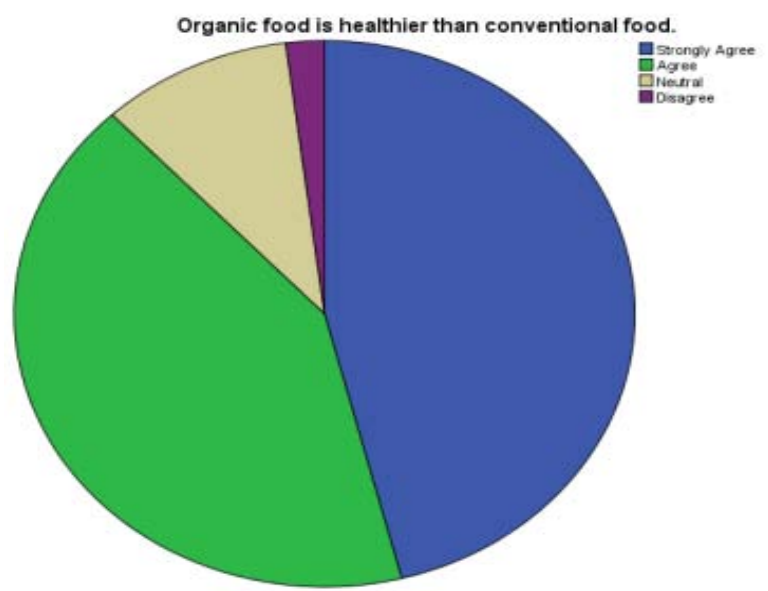

Figure 1: Organic food is healthier than conventional food 


\section{International Journal of Science and Research (IJSR) \\ ISSN (Online): 2319-7064}

Index Copernicus Value (2013): 6.14 | Impact Factor (2014): 5.611

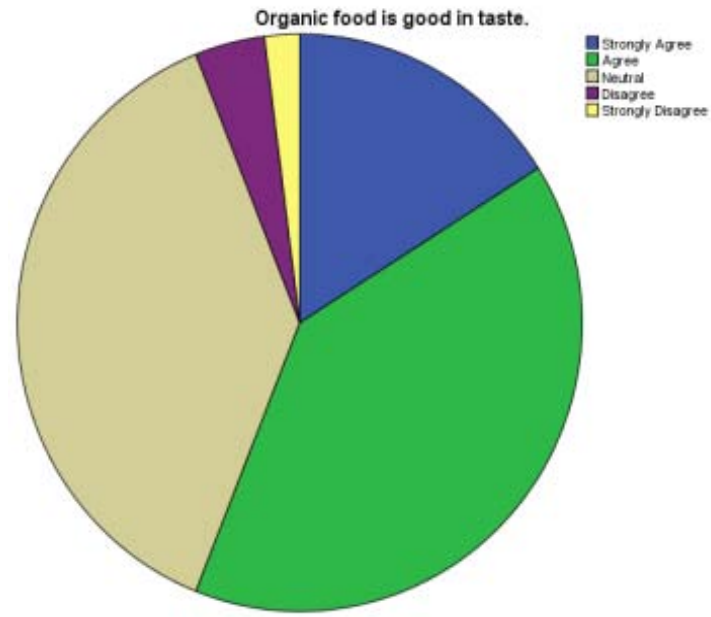

Figure 2: Organic food is good in taste

Table 5: Organic Food is less preservative

\begin{tabular}{|c|c|c|c|c|c|}
\hline \multicolumn{2}{|c|}{} & Frequency & Percent & $\begin{array}{c}\text { Valid } \\
\text { Percent }\end{array}$ & $\begin{array}{c}\text { Cumulative } \\
\text { Percent }\end{array}$ \\
\hline \multirow{4}{*}{ Valid } & Strongly Agree & 16 & 16.0 & 16.0 & 16.0 \\
\cline { 2 - 6 } & Agree & 56 & 56.0 & 56.0 & 72.0 \\
\cline { 2 - 6 } & Neutral & 26 & 26.0 & 26.0 & 98.0 \\
\cline { 2 - 6 } & Disagree & 2 & 2.0 & 2.0 & 100.0 \\
\cline { 2 - 6 } & Total & 100 & 100.0 & 100.0 & \\
\hline
\end{tabular}

Interpretation of the results: Results shows that $72 \%$ consumers are agree that organic food is less preservative. Consumers are aware that organic farming is better for soil. Studies shows that organic fields have deeper vegetation, more weed cover, and contain $88 \%$ more ,epigeal arthropodse $^{\text {ee }}$ (squiggly soil creatures, Ecology and Farming Magazine, IFOAM, Sept/Dec 1996). The products are chemical free resulting in no side effects and do not cause harm to persons consuming organic food products.

Table 6: Organic Food is better in Quality than Conventional Food

\begin{tabular}{|c|c|c|c|c|c|}
\hline & & Frequency & Percent & $\begin{array}{c}\text { Valid } \\
\text { Percent }\end{array}$ & $\begin{array}{c}\text { Cumulative } \\
\text { Percent }\end{array}$ \\
\hline \multirow{5}{*}{ Valid } & Strongly Agree & 30 & 30.0 & 30.0 & 30.0 \\
\hline & Agree & 58 & 58.0 & 58.0 & 88.0 \\
\hline & Neutral & 8 & 8.0 & 8.0 & 96.0 \\
\hline & Disagree & 4 & 4.0 & 4.0 & 100.0 \\
\hline & Total & 100 & 100.0 & 100.0 & \\
\hline
\end{tabular}

Interpretation of the results: When we ask to the consumers about the quality of organic food, $88 \%$ consumers were agreed that the organic food is better in quality than the conventional food. The survey shows that consumers are more and more concerned with the environmental and health issues at the moment. They show an increasing attention toward the health, nutrition and safety issues. The choice of food nutrition and the importance of hygiene are observed from many studies.

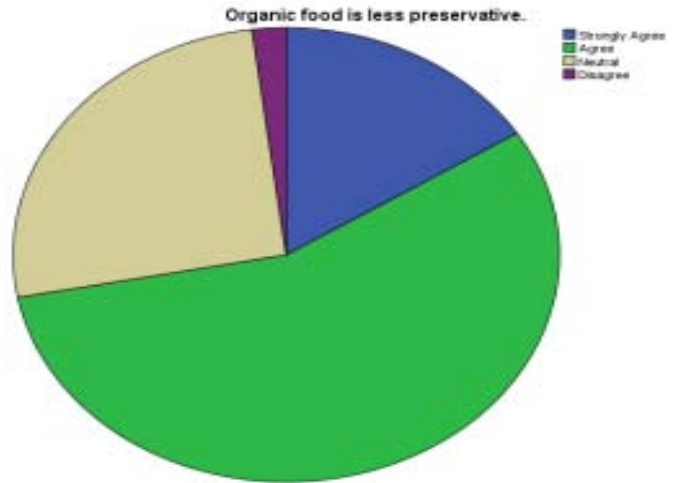

Figure 3: Organic food is less perspective

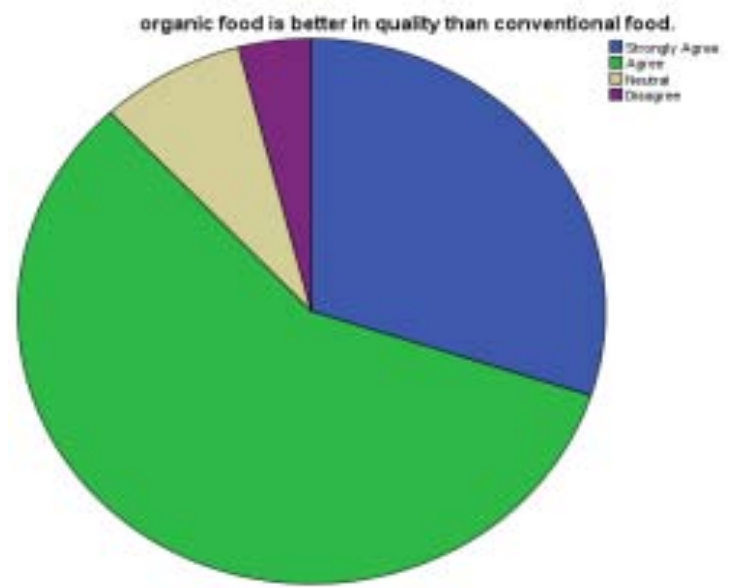

Figure 4: Organic food is better in quality than conventional food

Table 7: Organic Food is more hygienic

\begin{tabular}{|c|c|c|c|c|c|}
\hline & & Frequency & Percent & $\begin{array}{c}\text { Valid } \\
\text { Percent }\end{array}$ & $\begin{array}{c}\text { Cumulative } \\
\text { Percent }\end{array}$ \\
\hline \multirow{5}{*}{ Valid } & Strongly Agree & 32 & 32.0 & 32.0 & 32.0 \\
\hline & Agree & 48 & 48.0 & 48.0 & 80.0 \\
\hline & Neutral & 18 & 18.0 & 18.0 & 98.0 \\
\hline & Strongly Disagree & 2 & 2.0 & 2.0 & 100.0 \\
\hline & Total & 100 & 100.0 & 100.0 & \\
\hline
\end{tabular}

Interpretation of the results: From the survey $32 \%$ consumers are strongly agree and $48 \%$ are agree about the hygiene of organic food. However $18 \%$ people are neutral about this statement. Only $2 \%$ people are disagreeing that organic food are more hygienic. This shows that in majority of consumers are believes that organic food is more hygienic than conventional food.

Table 8: Fruits and Vegetables are the healthiest Organic food

\begin{tabular}{|c|l|l|l|l|l|}
\hline \multicolumn{2}{|c|}{} & Frequency & Percent & $\begin{array}{l}\text { Valid } \\
\text { Percent }\end{array}$ & $\begin{array}{l}\text { Cumulative } \\
\text { Percent }\end{array}$ \\
\hline \multirow{8}{*}{ Valid } & Strongly Agree & 46 & 46.0 & 46.0 & 46.0 \\
\cline { 2 - 6 } & Agree & 36 & 36.0 & 36.0 & 82.0 \\
\cline { 2 - 6 } & Neutral & 10 & 10.0 & 10.0 & 92.0 \\
\cline { 2 - 6 } & Disagree & 4 & 4.0 & 4.0 & 96.0 \\
\cline { 2 - 6 } & Strongly Disagree 4 & 4.0 & 4.0 & 100.0 \\
\cline { 2 - 6 } & Total & 100 & 100.0 & 100.0 & \\
\hline
\end{tabular}

Interpretation of the results: According to the survey, consumers believe that fruits and vegetables are healthiest organic food. Only $8 \%$ people are disagreeing from this

\section{Volume 5 Issue 2, February 2016}




\section{International Journal of Science and Research (IJSR) \\ ISSN (Online): 2319-7064 \\ Index Copernicus Value (2013): 6.14 | Impact Factor (2014): 5.611}

statement. There is evidence that some organic fruit is drier than conventionally grown fruit; a slightly dried fruit may also have a more intense flavor due to the higher concentration of flavoring substances.

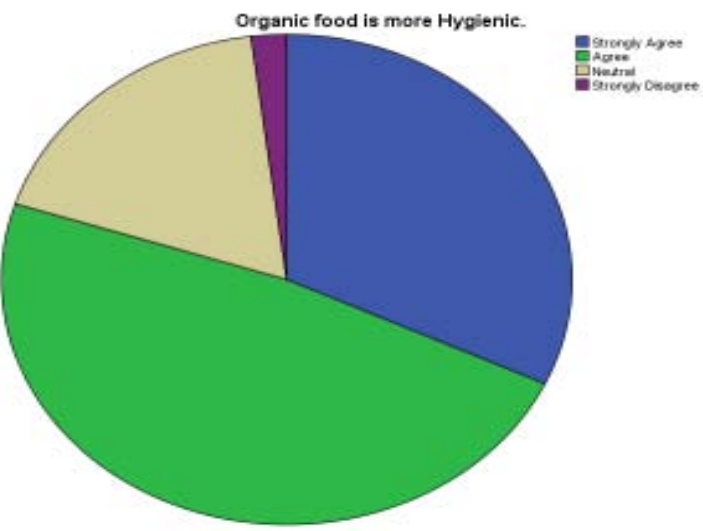

Figure 5: Organic Food is more hygienic

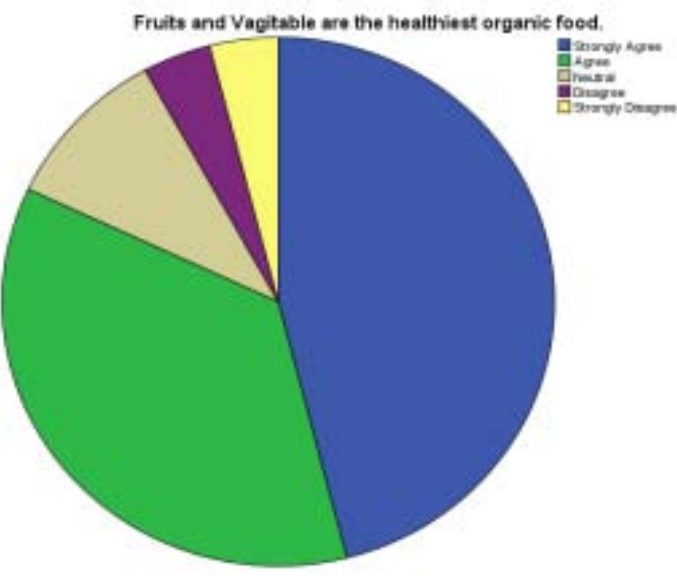

Figure 6: Fruits and Vegetables are the healthiest Organic food

Table 9: Organic food is less consumed and bought because of lack of availability

\begin{tabular}{|c|c|c|c|c|c|}
\hline \multicolumn{2}{|c|}{} & Frequency & Percent & $\begin{array}{c}\text { Valid } \\
\text { Percent }\end{array}$ & $\begin{array}{c}\text { Cumulative } \\
\text { Percent }\end{array}$ \\
\hline \multirow{7}{*}{} & Strongly Agree & 36 & 36.0 & 36.0 & 36.0 \\
\cline { 2 - 6 } & Agree & 32 & 32.0 & 32.0 & 68.0 \\
\cline { 2 - 6 } & Neutral & 18 & 18.0 & 18.0 & 86.0 \\
\cline { 2 - 6 } & Disagree & 12 & 12.0 & 12.0 & 98.0 \\
\cline { 2 - 6 } & Strongly & 2 & 2.0 & 2.0 & 100.0 \\
\cline { 2 - 6 } & Disagree & & 100.0 & 100.0 & \\
\cline { 2 - 6 } & Total & 100 & & & \\
\hline
\end{tabular}

Table 10: Organic food is less consumed and bought because of lack of awareness

\begin{tabular}{|c|c|c|c|c|c|}
\hline \multicolumn{2}{|c|}{} & Frequency & Percent & $\begin{array}{c}\text { Valid } \\
\text { Percent }\end{array}$ & $\begin{array}{c}\text { Cumulative } \\
\text { Percent }\end{array}$ \\
\hline \multirow{4}{*}{ Valid } & Strongly Agree & 30 & 30.0 & 30.0 & 30.0 \\
\cline { 2 - 6 } & Agree & 40 & 40.0 & 40.0 & 70.0 \\
\cline { 2 - 6 } & Neutral & 18 & 18.0 & 18.0 & 88.0 \\
\cline { 2 - 6 } & Disagree & 12 & 12.0 & 12.0 & 100.0 \\
\cline { 2 - 6 } & Total & 100 & 100.0 & 100.0 & \\
\hline
\end{tabular}

Interpretation of the results: As the table shows majority of people were agreed from these statements that the availability and lack of awareness is the major reason for less consumption of organic food. There is a high requirement to aware the consumers of rural and semi urban areas and also aware them for the benefits of organic food by making the marketing policies.

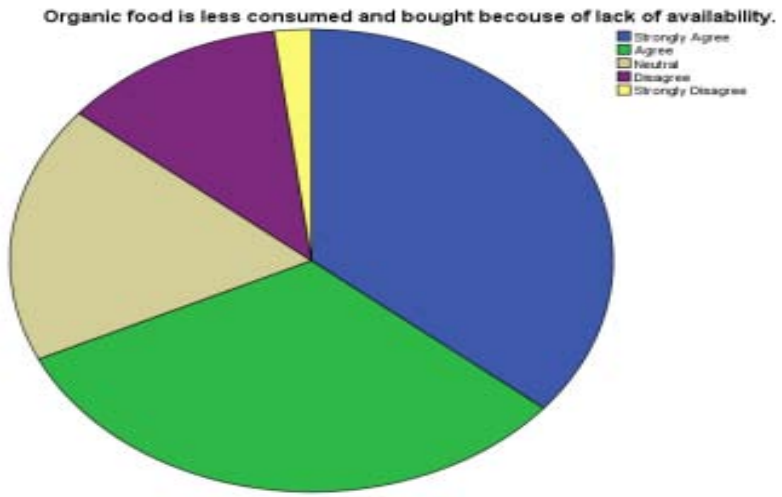

Figure 7: Organic food is less consumed and bought because of lack of availability

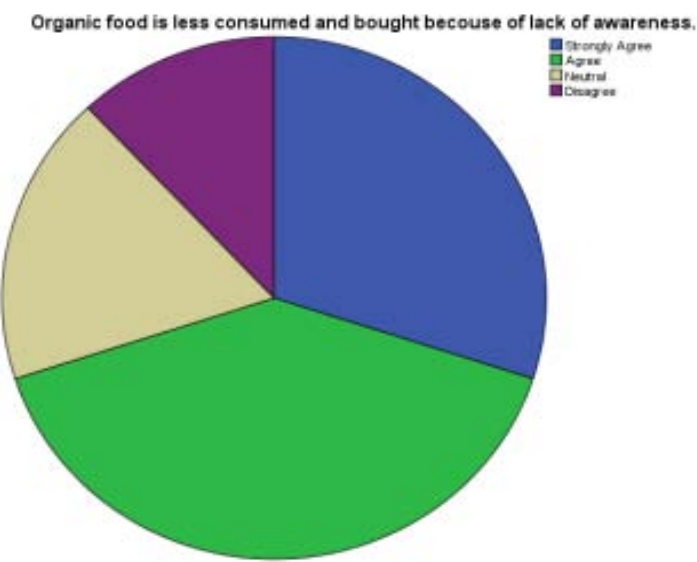

Figure 7: Organic food is less consumed and bought because of lack of awareness

Table 11: I would rather buy Organic food products even though it is expensive

\begin{tabular}{|c|l|l|l|l|l|}
\hline \multicolumn{2}{|c|}{} & Frequency & Percent & $\begin{array}{c}\text { Valid } \\
\text { Percent }\end{array}$ & $\begin{array}{c}\text { Cumulative } \\
\text { Percent }\end{array}$ \\
\hline \multirow{4}{*}{ Valid } & Strongly Agree & 16 & 16.0 & 16.0 & 16.0 \\
\cline { 2 - 6 } & Agree & 44 & 44.0 & 44.0 & 60.0 \\
\cline { 2 - 6 } & Neutral & 32 & 32.0 & 32.0 & 92.0 \\
\cline { 2 - 6 } & Disagree & 8 & 8.0 & 8.0 & 100.0 \\
\cline { 2 - 6 } & Total & 100 & 100.0 & 100.0 & \\
\hline
\end{tabular}

Interpretation of the results: if the people are fully aware about the organic food then people are ready to pay the premium price for this. $60 \%$ people were agreed with the statement but $32 \%$ people were neutral on this statement.

Table 12: I prefer to purchase from supermarket

\begin{tabular}{|c|c|c|c|c|c|}
\hline \multicolumn{2}{|c|}{} & Frequency & Percent & $\begin{array}{c}\text { Valid } \\
\text { Percent }\end{array}$ & $\begin{array}{c}\text { Cumulative } \\
\text { Percent }\end{array}$ \\
\hline \multirow{4}{*}{ Valid } & Strongly Agree & 10 & 10.0 & 10.0 & 10.0 \\
\cline { 2 - 6 } & Agree & 38 & 38.0 & 38.0 & 48.0 \\
\cline { 2 - 6 } & Neutral & 28 & 28.0 & 28.0 & 76.0 \\
\cline { 2 - 6 } & Disagree & 22 & 22.0 & 22.0 & 98.0 \\
\cline { 2 - 6 } & Strongly Disagree & 2 & 2.0 & 2.0 & 100.0 \\
\cline { 2 - 6 } & Total & 100 & 100.0 & 100.0 & \\
\hline
\end{tabular}




\section{International Journal of Science and Research (IJSR) \\ ISSN (Online): 2319-7064}

Index Copernicus Value (2013): 6.14 | Impact Factor (2014): 5.611

Table 13: I prefer to purchase from local market

\begin{tabular}{|c|c|c|c|c|c|}
\hline \multicolumn{2}{|c|}{} & Frequency & Percent & $\begin{array}{c}\text { Valid } \\
\text { Percent }\end{array}$ & $\begin{array}{c}\text { Cumulative } \\
\text { Percent }\end{array}$ \\
\hline \multirow{7}{*}{ Valid } & Agree & 38 & 38.0 & 38.0 & 38.0 \\
\cline { 2 - 6 } & Neutral & 38 & 38.0 & 38.0 & 76.0 \\
\cline { 2 - 6 } & Disagree & 18 & 18.0 & 18.0 & 94.0 \\
\cline { 2 - 6 } & $\begin{array}{c}\text { Strongly } \\
\text { Disagree }\end{array}$ & 6 & 6.0 & 6.0 & 100.0 \\
\cline { 2 - 6 } & Total & 100 & 100.0 & 100.0 & \\
\hline
\end{tabular}

Table 14: I prefer to purchase Organic food once a week

\begin{tabular}{|c|c|c|c|c|c|}
\hline \multicolumn{2}{|c|}{} & Frequency & Percent & $\begin{array}{c}\text { Valid } \\
\text { Percent }\end{array}$ & $\begin{array}{c}\text { Cumulative } \\
\text { Percent }\end{array}$ \\
\hline \multirow{4}{*}{ Valid } & Strongly Agree & 8 & 8.0 & 8.0 & 8.0 \\
\cline { 2 - 6 } & Agree & 40 & 40.0 & 40.0 & 48.0 \\
\cline { 2 - 6 } & Neutral & 26 & 26.0 & 26.0 & 74.0 \\
\cline { 2 - 6 } & Disagree & 16 & 16.0 & 16.0 & 90.0 \\
\cline { 2 - 6 } & $\begin{array}{c}\text { Strongly } \\
\text { Disagree }\end{array}$ & 10 & 10.0 & 10.0 & 100.0 \\
\cline { 2 - 6 } & Total & 100 & 100.0 & 100.0 & \\
\hline
\end{tabular}

Table 15: I prefer to purchase Organic food every fortnight

\begin{tabular}{|c|c|c|c|c|c|}
\hline \multicolumn{2}{|c|}{} & Frequency & Percent & $\begin{array}{c}\text { Valid } \\
\text { Percent }\end{array}$ & $\begin{array}{c}\text { Cumulative } \\
\text { Percent }\end{array}$ \\
\hline \multirow{4}{*}{ Valid } & Agree & 20 & 20.0 & 20.0 & 20.0 \\
\cline { 2 - 6 } & Neutral & 38 & 38.0 & 38.0 & 58.0 \\
\cline { 2 - 6 } & Disagree & 24 & 24.0 & 24.0 & 82.0 \\
\cline { 2 - 6 } & $\begin{array}{c}\text { Strongly } \\
\text { Disagree }\end{array}$ & 18 & 18.0 & 18.0 & 100.0 \\
\cline { 2 - 6 } & Total & 100 & 100.0 & 100.0 & \\
\hline
\end{tabular}

Table 16: I prefer to purchase Organic food monthly

\begin{tabular}{|c|c|c|c|c|c|}
\hline \multicolumn{2}{|c|}{} & Frequency & Percent & $\begin{array}{c}\text { Valid } \\
\text { Percent }\end{array}$ & $\begin{array}{c}\text { Cumulative } \\
\text { Percent }\end{array}$ \\
\hline \multirow{4}{*}{ Valid } & Strongly Agree & 2 & 2.0 & 2.0 & 2.0 \\
\cline { 2 - 6 } & Agree & 14 & 14.0 & 14.0 & 16.0 \\
\cline { 2 - 6 } & Neutral & 44 & 44.0 & 44.0 & 60.0 \\
\cline { 2 - 6 } & Disagree & 34 & 34.0 & 34.0 & 94.0 \\
\cline { 2 - 6 } & $\begin{array}{c}\text { Strongly } \\
\text { Disagree }\end{array}$ & 6 & 6.0 & 6.0 & 100.0 \\
\cline { 2 - 6 } & Total & 100 & 100.0 & 100.0 & \\
\hline
\end{tabular}

Table 17: I prefer to purchase Organic food every two months

\begin{tabular}{|c|c|c|c|c|c|}
\hline \multicolumn{2}{|c|}{} & Frequency & Percent & $\begin{array}{c}\text { Valid } \\
\text { Percent }\end{array}$ & $\begin{array}{c}\text { Cumulative } \\
\text { Percent }\end{array}$ \\
\hline \multirow{4}{*}{ Valid } & Strongly Agree & 6 & 6.0 & 6.0 & 6.0 \\
\cline { 2 - 6 } & Agree & 12 & 12.0 & 12.0 & 18.0 \\
\cline { 2 - 6 } & Neutral & 24 & 24.0 & 24.0 & 42.0 \\
\cline { 2 - 6 } & Disagree & 40 & 40.0 & 40.0 & 82.0 \\
\cline { 2 - 6 } & Strongly Disagree & 18 & 18.0 & 18.0 & 100.0 \\
\cline { 2 - 6 } & Total & 100 & 100.0 & 100.0 & \\
\hline
\end{tabular}

Interpretation of the results: The survey shows that consumers are ready to purchase their nearby market from where it can be easily available. The availability of any products plays major role for the increase of purchasing and consuming of the products. The table shows that customers are purchase the organic food according to their requirements
Table 18: Organic food is comparatively expensive than Conventional food

\begin{tabular}{|c|l|l|l|l|l|}
\hline \multicolumn{2}{|c|}{} & Frequency & Percent & $\begin{array}{l}\text { Valid } \\
\text { Percent }\end{array}$ & $\begin{array}{l}\text { Cumulative } \\
\text { Percent }\end{array}$ \\
\hline \multirow{4}{*}{ Valid } & Strongly Agree & 20 & 20.0 & 20.0 & 20.0 \\
\cline { 2 - 6 } & Agree & 44 & 44.0 & 44.0 & 64.0 \\
\cline { 2 - 6 } & Neutral & 32 & 32.0 & 32.0 & 96.0 \\
\cline { 2 - 6 } & Disagree & 4 & 4.0 & 4.0 & 100.0 \\
\cline { 2 - 6 } & Total & 100 & 100.0 & 100.0 & \\
\hline
\end{tabular}

Interpretation of the results: Majority of customers were agreed with the statement that organic food is more expensive than the conventional food.

Table 19: Organic food is available in good packaging to attract customers

\begin{tabular}{|c|c|c|c|c|c|}
\hline \multicolumn{2}{|c|}{} & Frequency & Percent & $\begin{array}{c}\text { Valid } \\
\text { Percent }\end{array}$ & $\begin{array}{c}\text { Cumulative } \\
\text { Percent }\end{array}$ \\
\hline \multirow{4}{*}{ Valid } & Strongly Agree & 12 & 12.0 & 12.0 & 12.0 \\
\cline { 2 - 6 } & Agree & 32 & 32.0 & 32.0 & 44.0 \\
\cline { 2 - 6 } & Neutral & 26 & 26.0 & 26.0 & 70.0 \\
\cline { 2 - 6 } & Disagree & 30 & 30.0 & 30.0 & 100.0 \\
\cline { 2 - 6 } & Total & 100 & 100.0 & 100.0 & \\
\hline
\end{tabular}

Interpretation of the results : $44 \%$ consumers are strongly agree and agree with the statement that the organic foods packaging are made to attract customers even $26 \%$ are neutral but $30 \%$ customers are disagreed with the statement.

Table 20: The buying of Organic food is rationally proportional to monthly income

\begin{tabular}{|c|c|c|c|c|c|}
\hline \multicolumn{2}{|c|}{} & Frequency & Percent & $\begin{array}{c}\text { Valid } \\
\text { Percent }\end{array}$ & $\begin{array}{c}\text { Cumulative } \\
\text { Percent }\end{array}$ \\
\hline \multirow{7}{*}{$\begin{array}{c}\text { Strongly } \\
\text { Agree }\end{array}$} & 8 & 8.0 & 8.0 & 8.0 \\
\cline { 2 - 6 } Valid & Agree & 38 & 38.0 & 38.0 & 46.0 \\
\cline { 2 - 6 } & Neutral & 32 & 32.0 & 32.0 & 78.0 \\
\cline { 2 - 6 } & Disagree & 18 & 18.0 & 18.0 & 96.0 \\
\cline { 2 - 6 } & $\begin{array}{c}\text { Strongly } \\
\text { Disagree }\end{array}$ & 4 & 4.0 & 4.0 & 100.0 \\
\cline { 2 - 6 } & Total & 100 & 100.0 & 100.0 & \\
\hline
\end{tabular}

Interpretation of the results: $38 \%$ customers were agreed that buying of organic food is rationally proportional to the monthly Income. Whereas $32 \%$ are neutral with this. Some loyal customer is disagreeing with the statement. They even habitual of the food and will not do any compromise. It shows that the Income also plays major role on the organic food consumption. In urban areas buying and consuming organic food has become status symbol for the rich. The survey shows that $68 \%$ customers were agreed with the statement $18 \%$ customers were disagreeing with this statement.

\section{Discussion \& Suggestions for Improvement of Awareness of Organic food}

Organic food companies should step ahead to create awareness amongst consumers about organic food. The organic food companies should try to explore the consumerse behavior to prepare tempting offer for them. 


\section{International Journal of Science and Research (IJSR) \\ ISSN (Online): 2319-7064}

Index Copernicus Value (2013): 6.14 | Impact Factor (2014): 5.611

1) There should be local market for organic food.

2) Requirement of organic shops in rural or urban areas.

3) Can also provide roadside stalls in the countryside.

4) The organic food can sale directly at the farm where the food was produced.

5) Online ordering of organic food delivered to the door to door.

6) Supermarket can expand the organic food products range.

7) In school meals, canteens cafeterias and high profile companies can include organic food in menu chart.

8) Maximum set up of organic production units.

9) Setting up packaging units for organic food.

10) Local and regional market development for organic food.

\section{Conclusion}

This study found that consumers are very much aware that organic food are good for health, these products are free from chemical which resulting in no side effects and do not cause harm to the consumers, who consume organic food products. The consumers living in urban areas are more aware about organic food products. This study also found that majority of the respondents are preferred to purchase organic food but lack of availability is the major issue. They also believe that consuming of organic food helps to reduce stress level and maintain an energetic lifestyle. Another factor this study found that respondents are willing to pay even higher prices because of it is beneficial for health.

\section{References}

[1] Sabeson, R., 1992, "Consumer preference towards processed fruits and vegetable products- a case study in Coimbatorecity". MSc (Agri) Thesis (unpublished) Tamil Nadu Agril Univ. Coimbatore.

[2] Fagerli RA, Wandel M, 1999. "Gender differences in opinions and practices with regard to a healthy diet. Appetite" 32:171-190.

[3] Brown, K., Mcllveen, H., and Strugnell, C., 2000, "Nutritional awareness and food Preferences of young consumers in Northern Ireland. Nutrition and food Sci". $30(4 / 5): 230-235$.

[4] Gil JM, Gracia A, Sánchez M, 2000. "Market segmentation and willingness to pay for organic products in Spain. Int Food Agribus Manage" Rev 3: 207-226.

[5] 2001 Lyons, K, Lockie, S and Lawrence, G (2001) "Consuming „Green": the Symbolic Construction of Organic Foods. Rural Society”, 11(3), 197-210.

[6] Bourne D, Prescott J, 2002. "A comparison of the nutritional value, sensory qualities, and food safety of organically and conventionally produced foods". Crit Rev Food sci nutr 42(1): 1-34.

[7] Brown, M.; Lee, J. "Restrictions on the effects of preference variables in the Rotterdam model. J. Agric. Appl. Econ." 2002, 34, 17-26.

[8] Sanjuán AI, Sanchez M, Gil JM, Gracia A, Soler F, 2003. "Brakes to organic market enlargement in Spain: consumers" and retailers"e attitudes and willing to pay". Int J Consum Stud 27(2): 134-144.
[9] Lockie s., Lyons k., Lawrence g., Grice j., 2004. "Choosing organics: a path analysis of factors underlying the selection of organic food among Australian consumers. Appetite" 43, 135-146.

[10]Padel, S and Foster, C (2005) "Exploring the gap between attitudes and behaviour: Understanding why consumers buy or do not buy organic food". British Food Journal,107 (8), 606-625.

[11] Yiridoe, E.K., Bonti-Ankomah, S. \& Martin, R.C. (2005), "Comparison of consumers perceptions and preferences toward organic versus conventionally produced foods: A review and update of the literature", Renewable Agriculture and Food System, Vol.20, pp.193-205

[12] A. Gracia, T. de "Magistracy, Organic food product purchase behavior a pilot study for urban consumers in the South of Italy", Spanish Journal of Agricultural Research 2007 5(4), 439-451

[13] Schobesberger-Roitner, B.; Darnhofer, I.; Somsook, S.; Vogl, C.R. Consumer perceptions of organic foods in Bangkok, Thailand. Food Policy 2008, 33, 112-121.

[14]Lin H Bling, Yen T Steven; U.S. Demand for Organic and Conventional Fresh Fruits: The Roles of Income and Price: Sustainability

[15] Samantha Smith, Angela Paladino, Eating clean \& green? Investigating consumer motivations towards the purchase of organic food, Anzmac 2009

[16] Ergin A Elif, Ozsacmaci Bulent; Turkish consumers"e perceptions and consumption of organic foods, African Journal of Business Management Vol. 5(3), pp. 910-914, 4 February, 2011.

[17]R. Olivas and R. Bernabéu, "Men"s and women"s attitudes toward organic food consumption. A Spanish case study, Spanish Journal of Agricultural Research 2012 10(2), 281-29.

[18] Olga Kutnohorska, Pavel Tomsik, "Consumers" perception of the health aspects of organic Food " Agric.Econ.czech, 59, 2013 (7): 293-299.

[19] Siti Sarah Mohamad, Syezreen Dalina Rusdi, Nor Hashima Hashim, Organic Food Consumption Among Urban

[20]Consumers: Preliminary Results, Procedia - Social and Behavioral Sciences 130 ( 2014 ) 509 - 514, Incomar 2013.

[21] Marangaz Mehmet, Paksoyah Mustafa, Sadettin, Modeling attitude towards organic foods: A research on adolescents, Business Management Dynamics. Vol.3, No.7, Jan 2014, pp.40-49

[22] Olusola Olugbenga Ibitoye, Nolila Mohd Nawi,Norsida Man and Nitty Hirawaty Kamarulzaman Factors Influencing Consumers' Purchasing Behaviour towards Organic Rice in Malaysia, World Applied Sciences Journal 32 (4): 611-617, 2014

\section{Authors Profile}

Dr. Geetika Sharma is working as Head of Department in College of Management, SUS College of Engineering \& Technology, Mohali, India. She has done PhD. in Management. 


\section{International Journal of Science and Research (IJSR) \\ ISSN (Online): 2319-7064}

Index Copernicus Value (2013): 6.14 | Impact Factor (2014): 5.611

Dr. Rakhee Dewan is working as Associate Professor in College of Management, SUS College of Engineering \& Technology, Mohali, India. She has done PhD. in Management.

Ms. Santosh Bali is working as Program Manager in Chitkara University, Punjab, India. She has done Masters Degree in Economics and Masters in Business Administration. Presently she is pursuing $\mathrm{PhD}$ in Management from Punjab Technical University,

Kapurthala. 